\title{
The effects of alcohol in newborns
}

\author{
Efeitos do álcool no recém-nascido
}

\author{
Maria dos Anjos Mesquita*
}

\begin{abstract}
The purpose of this article was to present a review of the effects of alcohol consumption by pregnant mothers on their newborn. Definitions, prevalence, pathophysiology, clinical features, diagnostic criteria, follow-up, treatment and prevention were discussed. A search was performed in Medline, LILACS, and SciELO databases using the following terms: "fetus", "newborn", "pregnant woman", "alcohol", "alcoholism", "fetal alcohol syndrome", and "alcoholrelated disorders". Portuguese and English articles published from 2000 to 2009 were reviewed. The effects of alcohol consumed by pregnant women on newborns are extremely serious and occur frequently; it is a major issue in Public Health worldwide. Fetal alcohol spectrum disorders cause harm to individuals, their families, and the entire society. Nevertheless, diagnostic difficulties and inexperience of healthcare professionals result in such damage, being remembered rarely or even remaining uncovered. Alcohol-related injury to the fetus is fully avoidable; all it takes is for women not to drink alcoholic beverages during pregnancy. Therefore, detecting women who consume alcohol during pregnancy is paramount, as are specific programs to educate people about the consequences of alcohol use during pregnancy and breastfeeding.
\end{abstract}

Keywords: Alcoholic beverages/adverse effects; Fetus; Infant, newborn; Fetal alcohol syndrome; Alcohol-related disorders

\section{RESUMO}

0 objetivo deste artigo foi 0 de apresentar uma revisão atualizada sobre as repercussões do consumo de álcool pela gestante no recém-nascido, abordando definições, prevalência, fisiopatologia, características clínicas, critérios diagnósticos, seguimento, tratamento e prevenção. 0 método usado para a elaboração deste artigo foi o levantamento bibliográfico da literatura médica por meio de busca na base de dados Medline, LILACS e na plataforma SciELO usando-se os termos: "feto", "recém-nascido", "gestante", "álcool", "alcoolismo", "síndrome alcoólica fetal" e "transtornos relacionados ao uso de álcool", abrangendo o período de 2000 a 2009, nos idiomas português e inglês. Concluiu-se que os efeitos do álcool no recémnascido, consequentes do consumo dessa droga pelas gestantes, são extremamente graves e frequentes, representando um importante problema de Saúde Pública mundial. 0 espectro de desordens fetais alcoólicas leva a prejuízos individuais, para a sua família e para toda a sociedade. Apesar disso, a dificuldade do seu diagnóstico e a inexperiência dos profissionais de saúde faz com que o espectro dessas lesões seja pouco lembrado e até desconhecido. As lesões causadas pela ação do álcool no concepto são totalmente prevenidas se a gestante não consumir bebidas alcoólicas durante a gestação. Assim, é fundamental a detecção das mulheres consumidoras de álcool durante a gravidez e 0 desenvolvimento de programas específicos de alerta sobre as consequências do álcool durante a gestação e amamentação.

Descritores: Bebidas alcoólicas/efeitos adversos; Feto; Recém-nascido; Síndrome alcoólica fetal; Transtornos relacionados ao uso de álcool

\section{INTRODUCTION}

Use of alcoholic beverages by pregnant women may result in abortion, fetal mortality and prematurity ${ }^{(1)}$. Alcohol consumed during pregnancy may harm embryos and fetuses; such damage is referred to as fetal alcohol spectrum disorders (FASD). Damage includes changes in physical, mental, behavioral and/ or learning abilities, which may be irreversible; they may also cause alcohol and other drug dependence, mental problems, impaired learning, difficulties at work, inappropriate sexual behavior, and difficulties with the law ${ }^{(1-3)}$.

The fetal alcohol syndrome (FAS), alcoholrelated birth defects (ARBD), and alcohol-related neurodevelopmentaldisorders(ARND) areencompassed by the term FASD, the most severe being FAS $^{(1-3)}$.

FASD are a major Public Health issue worldwide ${ }^{(4)}$.

According to Secretaria Nacional Antidrogas (SENAD), Brazil and the World Health Organization (WHO), most countries have witnessed a significant increase in alcohol consumption in recent decades; alcohol is currently the most consumed drug in the world ${ }^{(5-6)}$. About 2 billion people consume alcoholic beverages, according to WHO data from $2004^{(5)}$.

\footnotetext{
*MD; Neonatologist of Hospital Maternidade Cruz Azul and Hospital Maternidade Escola Vila Nova Cachoeirinha "Dr. Mário de Moraes Altenfelder Silva", São Paulo (SP), Brazil.

Corresponding author: Maria dos Anjos Mesquita - Rua Marechal Hermes da Fonseca, 185, apto 43 - Santana - CEP 02020-000 - São Paulo (SP), Brasil -E-mail: manjosmesquita@uol.com.br

Received: Feb 17, 2010 - Accepted: Jul 16, 2010

Conflict of interest: none.
} 
In 2002, the WHO diagnosed alcoholism as the main health issue in Latin America - even in Brazil - and the most important factor reducing the life expectancy of Brazilians $^{(7)}$.

\section{OBJECTIVE}

The purpose of this study was to review relevant articles on the effects of alcohol consumption by pregnant women on their newborn.

\section{METHODS}

A survey of the medical literature was carried out in the Medline, LILACS, and SciELO databases and in textbooks. The following keywords were used: "fetus", "newborn", "pregnant woman", "alcohol", "alcoholism", "fetal alcohol syndrome", and "alcoholrelated disorders". The study period was from 2000 to 2009, and Portuguese and English papers and texts were searched.

The following items were selected: "effects of ethyl alcohol"; "clinical features" and "diagnostic criteria of FASD"; "diagnosis, follow-up and treatment"; and "prevention".

\section{RESULTS}

Forty articles from 2000 to 2009 were chosen and were classified into categories (Chart 1); most were review articles/updates. Charts 2 to 7 present the diagnostic criteria and ARBD and ARND characteristics.

\section{DISCUSSION}

The First National Survey on Consumption Patterns of Alcohol in the Brazilian Population, published in 2007, revealed that $65 \%$ of men and $41 \%$ of women aged 18 or more drink alcoholic beverages at least once a year. This study also showed that among teenagers aged 14 to 17 years, $64 \%$ of males and $68 \%$ of females were considered teetotalers ${ }^{(5)}$.

Alcoholism is underdiagnosed in pregnancy since healthcare professionals are unprepared to make this diagnosis and because social prejudice in pregnancy causes women to hide their alcohol-consuming habits $^{(8)}$.

A study carried out in Rio de Janeiro, Brazil, in 2000, by Moraes and Reichenheim found that $40.6 \%$ of delivering patients consumed alcohol at some time during pregnancy, and that $10.1 \%$ consumed alcohol up to the end of pregnancy ${ }^{(8)}$. A study performed in São Paulo, Brazil, and published in 2009, found that $33.29 \%$ of delivering patients consumed alcohol at some time
Chart 1. Characteristics of the studies selected

\begin{tabular}{|c|c|}
\hline Study & Type \\
\hline Hoyme HE, et al. ${ }^{(1)}$ & Cohort study \\
\hline Bertrand J, et al. ${ }^{(2)}$ & Recommendations \\
\hline NCBDDD, et al. ${ }^{(3)}$ & Recommendations \\
\hline Riley EP, et al. ${ }^{(4)}$ & Review \\
\hline Felix JA $\mathrm{A}^{(5)}$ & Book chapter \\
\hline $\mathrm{WHO}^{(6)}$ & Statement \\
\hline $\mathrm{WHO} \mathrm{O}^{(7)}$ & Report \\
\hline Moraes CL, et al. ${ }^{(8)}$ & Cross-sectional study \\
\hline Mesquita MA, et al. ${ }^{(9)}$ & Cross-sectional study \\
\hline May PA, et al. ${ }^{(10)}$ & Case control study \\
\hline May PA, et al. ${ }^{(11)}$ & Review \\
\hline Ethen MK, et al. ${ }^{(12)}$ & Cohort study \\
\hline Warren $\mathrm{KR}$, et al. ${ }^{(13)}$ & Statement \\
\hline Jones MW, et al. ${ }^{(14)}$ & Review \\
\hline Lemoine $P$, et al. ${ }^{(15)}$ & Cohort study \\
\hline Jones KL, et al. ${ }^{16)}$ & Cohort study \\
\hline Lemoine P, et al. ${ }^{(17)}$ & Cross-sectional study \\
\hline Thackray H, et al. ${ }^{(18)}$ & Statement \\
\hline Hannigan JH, et al. ${ }^{(19)}$ & Review \\
\hline Astley SJ, et al. ${ }^{(20)}$ & Cross-sectional study \\
\hline Chudley AE, et al. ${ }^{(21)}$ & Recommendations \\
\hline U.S. Surgeon General Advisory ${ }^{1221}$ & Statement \\
\hline Grinfeld H. ${ }^{(23)}$ & Book chapter \\
\hline Nóbrega MPSS, et al $\left.\right|^{(24)}$ & Qualitative study \\
\hline Grinfeld $\mathrm{H}$, et al. ${ }^{(25)}$ & Review \\
\hline Mattson SN, et al. ${ }^{(26)}$ & Review \\
\hline Am. Acad. Pediatrics ${ }^{(27)}$ & Statement \\
\hline Maier SE, et al. ${ }^{(28)}$ & Update \\
\hline Goodlett CR,et al. ${ }^{(29)}$ & Review \\
\hline$N E A D^{(30)}$ & Review \\
\hline NOFAS ${ }^{(31)}$ & Update \\
\hline Roebuck-Spencer TM, et al. ${ }^{\mid 32)}$ & Cohort study \\
\hline Mennella JA ${ }^{(33)}$ & Review \\
\hline Menella JA, et al. ${ }^{(34)}$ & Cohort study \\
\hline Floyd RL, et al. ${ }^{(35)}$ & Update \\
\hline Peadon E, et al. ${ }^{(36)}$ & Update \\
\hline Gahagan S, et al. ${ }^{(37)}$ & Cohort study \\
\hline Cook JD ${ }^{(38)}$ & Review \\
\hline Peadon E, et al. ${ }^{(39)}$ & Review \\
\hline Pinheiro SN, et al. ${ }^{(40)}$ & Cross-sectional study \\
\hline
\end{tabular}

World Health Organization (WHO); National Institute on Alcohol

Abuse and Alcoholism (NIAAA).

during pregnancy, of which $21.41 \%$ consumed alcohol in all three gestational trimesters ${ }^{(9)}$.

Factors associated with alcohol consumption by pregnant women include early age ${ }^{(9)}$, low schooling level ${ }^{(8-10)}$, low monthly income ${ }^{(10,11)}$, not living with the partner ${ }^{(3,8-11)}$, living with other alcohol consumers ${ }^{(9-}$ 11), smoking ${ }^{(3,8-12)}$, use of illegal drugs ${ }^{(8,9,11)}$, unplanned pregnancy ${ }^{(9,12)}$, beginning prenatal control late ${ }^{(9)}$ and fewer prenatal medical visits ${ }^{(9)}$.

Fewer number of pregnancies, a more advanced education level, religious affiliation, a non-alcohol 
Chart 2. Characteristics found in children exposed to alcohol in the uterus

\begin{tabular}{|l|}
\hline Facial anomalies \\
\hline - small palpebral fissure \\
- palpebral ptosis \\
- flattened hemi-face \\
- anteverted nose \\
- smooth philtrum \\
- thin upper lip \\
\hline Growth restriction \\
\hline - low birth weight \\
- growth restriction despite appropriate nutrition \\
- low weight related to height \\
\hline Changes in CNS development \\
\hline - microcephaly \\
- structural brain abnormalities including agenesis of the corpus callosus and \\
cerebellar hypoplasia \\
- other neurological signs, such as fine motor difficulties, sensorineural hearing loss, \\
uncoordinated deambulation and impaired eye-hand coordination \\
\hline Unexplained behavioral abnormalities \\
\hline - impaired reading \\
- poor school achievement \\
- difficulty to control impulses \\
- problems with social perception \\
- language difficulty \\
- poor abstract rationale \\
- impaired skills \\
- impaired memory and judgment \\
\hline Congenital defects \\
\hline Including but not limited to: \\
- cardiac defects \\
- bone and limb deformities \\
- renal anatomical anomalies \\
- ophthalmologic alterations \\
- absence of the ear \\
- lip or palate cleft \\
\hline
\end{tabular}

Source: Thackray H, Tifft C. Fetal alcohol syndrome. Pediatr Rev. 2001;22(2):47-55.

Chart 4. Alcohol-related neurodevelopmental disorders (ARND)

\begin{tabular}{|l|}
\hline Confirmed maternal alcohol exposure and at least one of the following changes \\
\hline Structural \\
\hline One or more of the following: \\
- head circumference $\leq 10^{\text {th }}$ percentile \\
- abnormal CNS structural images \\
\hline Behavioral or cognitive abnormalities - inconsistent with development \\
level, that could not be explained by genetic predisposition, family history \\
or environmental factors: \\
\hline - decreased task performance \\
- complex problems \\
- planning \\
- judgment \\
- abstraction \\
- arithmetic \\
- deficits in language reception and expression \\
- behavioral disorders \\
- difficult personality \\
- emotional lability \\
- motor dysfunction \\
- poor school achievement \\
- poor social interaction \\
\hline
\end{tabular}

Source: Hoyme HE, May PA, Kalberg WO, Kodituwkku P, Gossage JP, Truillo PM, et al. A practical clinical approach to diagnosis of fetal alcohol spectrum disorders: clarification of the 1996 Institute of Medicine criteria. Pediatrics. 2005;115(1):39-47.
Chart 3. Alcohol-related birth defects (ARBD)

Confirmed maternal alcohol exposure, at least two facial characteristics and one or more of the following structural defects

Cardiac

- atrial septal defects

- ventricular septal defects

- aberrant great vessels

- conaltruncal heart defects

\section{Skeleton}

- pectus excavatum or carinatum

- scoliosis

- radioulnar synostosis

- vertebral segmentation defects

- large joints contractions

\section{Renal}

- renal aplasia, hypoplasia and/or dysplasia

- horseshoe kidneys

- urethral duplication

Ocular

- strabismus

- palpebral ptosis

- refraction errors

- retinal vascular anomalies

- optic nerve hypoplasia

\section{Ear}

- agenesia of auditory canal

- neurosensorial hearing loss

- conductive hearing loss

- prominent ear

\section{Minor anomalies}

- nasal hypoplasia

- small fingers

- clinodactyly

- camptodactyly

- hockey-stick palmar crease

- epicanthal fold

- flat nasal bridge

- facial hypoplasia

Source: Hoyme HE, May PA, Kalberg WO, Kodituwkku P, Gossage JP, Truilllo PM, et al. A practical clinical approach to diagnosis of fetal alcohol spectrum disorders: clarification of the 1996 Institute of Medicine criteria. Pediatrics. 2005;115(1):39-47.

Chart 5. Diagnostic criteria of the Institute of Medicine of the National Academy of Sciences for fetal alcohol syndrome (FAS) and alcohol-related effects

\begin{tabular}{|l|l|}
\hline $\begin{array}{l}\text { Category } \mathbf{1} \\
\text { exposure }\end{array}$ & $\begin{array}{l}\text { Patients in this category present the classic } \\
\text { triad of growth restriction, characteristic } \\
\text { facial dysmorphism and neurodevelopment } \\
\text { abnormalities. They are defined as complete FAS. }\end{array}$ \\
\hline $\begin{array}{l}\text { Category } \mathbf{2} \\
\text { FAS with no confirmed maternal } \\
\text { alcohol exposure }\end{array}$ & $\begin{array}{l}\text { If the triad described in category 1 is present, } \\
\text { the diagnosis of FAS is possible, even with no } \\
\text { confirmation of maternal alcohol exposure. }\end{array}$ \\
\hline $\begin{array}{l}\text { Category } \mathbf{3} \\
\text { Partial FAS with confirmed maternal } \\
\text { alcohol exposure }\end{array}$ & $\begin{array}{l}\text { Patients may present only some of the facial } \\
\text { characteristics associated to growth restriction, } \\
\text { abnormalities of neurodevelopment and/or of } \\
\text { cognitive behavior. }\end{array}$ \\
\hline $\begin{array}{l}\text { Category } \mathbf{4} \\
\text { FAS with confirmed maternal alcohol } \\
\text { exposure and alcohol-related birth } \\
\text { defects }\end{array}$ & $\begin{array}{l}\text { Patients of this category have some congenital } \\
\text { anomalies resulting from alcohol toxicity. }\end{array}$ \\
\hline $\begin{array}{l}\text { Category } \mathbf{5} \\
\text { FAS with confirmed maternal } \\
\text { alcohol exposure and alcohol-related } \\
\text { neurodevelopmental disorders }\end{array}$ & $\begin{array}{l}\text { abnormalities of CNS development and/or a } \\
\text { complex abnormal cognitive behavior pattern, but } \\
\text { may have no physical alteration. }\end{array}$ \\
\hline
\end{tabular}

Source: Hoyme HE, May PA, Kalberg WO, Kodituwkku P, Gossage JP, Trujillo PM, et al. A practical clinical approach to diagnosis of fetal alcohol spectrum disorders: clarification of the 1996 Institute of Medicine Criteria. Pediatrics. 2005:115(1):39-47. 
Chart 6. 4-Digit Diagnostic Code for FASD

\begin{tabular}{|c|c|c|c|c|}
\hline Scale & Growth restriction & FAS facial phenotype & CNS lesion or dysfunction & Gestational alcohol exposure \\
\hline 1 & $\begin{array}{c}\text { None } \\
\text { Length and weight greater than or equal } \\
\text { to } 10^{\text {th }} \text { percentile }\end{array}$ & $\begin{array}{c}\text { Absent } \\
\text { None of the three characteristics }\end{array}$ & $\begin{array}{c}\text { Slightly probable } \\
\text { No evidence or decreased structural, } \\
\text { neurological or functional evidence }\end{array}$ & $\begin{array}{c}\text { No risk } \\
\text { Confirmed absence of exposure from } \\
\text { conception to birth }\end{array}$ \\
\hline 3 & $\begin{array}{l}\text { Moderate } \\
\text { Length and weight lower than } 10^{\text {th }} \\
\text { percentile }\end{array}$ & $\begin{array}{c}\text { Moderate } \\
\text { Usually two of the three characteristics }\end{array}$ & $\begin{array}{c}\text { Probable } \\
\text { Significant dysfunction in three or more } \\
\text { domains }\end{array}$ & $\begin{array}{c}\text { Some risk } \\
\text { Confirmed exposure. Unknown level or } \\
\text { exposure or lower than scale } 4\end{array}$ \\
\hline 4 & $\begin{array}{c}\text { Significant } \\
\text { Length and weight lower than } 3^{\text {rd }} \\
\text { percentile }\end{array}$ & $\begin{array}{c}\text { Severe } \\
\text { All characteristics: } \\
\text { - Palpebral fissure below } 2 \text { or more } \\
\text { standard deviation } \\
\text { - Thin lip: score } 4 \text { or } 5 \\
\text { - Smooth philtrum: score } 4 \text { or } 5\end{array}$ & $\begin{array}{c}\text { Defined } \\
\text { Structural or neurological evidence }\end{array}$ & $\begin{array}{c}\text { High risk } \\
\text { Confirmed exposure at high levels }\end{array}$ \\
\hline
\end{tabular}

Source: Chudley AE, Conry J, Cook JL, Loock C, Rosales T, LeBlanc N. Fetal alcohol spectrum disorder: Canadian guidelines for diagnosis. CMAJ. 2005;172(5S):1-21.

Chart 7. Centers for Disease Control and Prevention diagnostic criteria for fetal alcohol syndrome

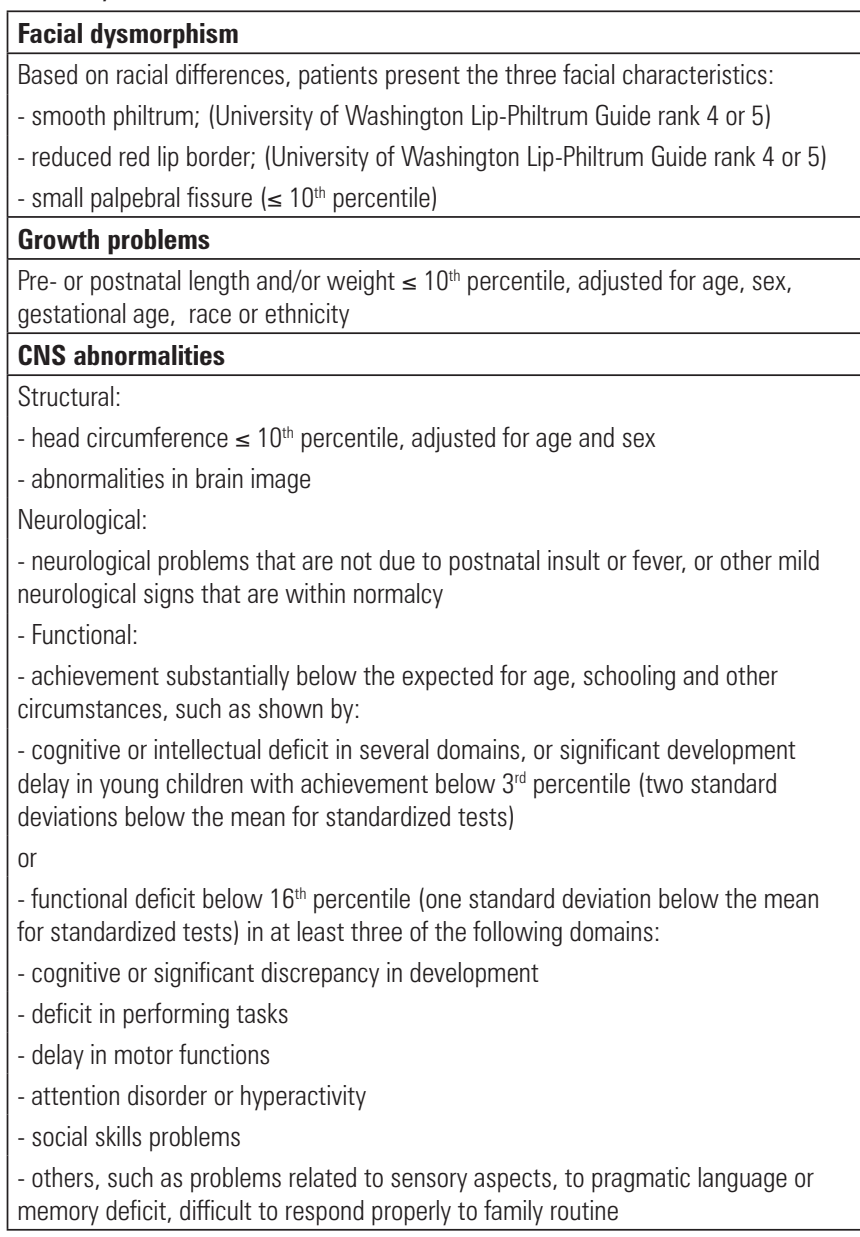

Source: Fetal alcohol syndrome: guidelines for referral and diagnosis. NCBDDD, CDC, DHHS, NTFFAS and FAE [Internet]. 2004 [cited 2009 Mar 9]. Available from: http://www.cdc.gov//ncbddd/fasd/documents/FAS guidelines_accessible.pdf.

consuming companion, and adequate nutrition are protective mechanisms against alcohol use in pregnancy; this has consequences for the prevention of the FAS ${ }^{(10)}$.

Alcoholconsumptionisaffectedbypharmacokynetic variations, especially genes involved in alcohol metabolism. The enzyme alcohol dehydrogenase contains the subunits beta 2 and beta 3 that result in a higher accumulation of acethylaldehyde, as compared to the beta1-containing enzyme ${ }^{(4)}$. Such forms, respectively encoded by the $\mathrm{ADH} 2 * 2$ and $\mathrm{ADH} 2 * 3$ alleles, are an important protective factor against alcoholism, because they decrease the frequency of alcohol consumption ${ }^{(4,13)}$. Acetyl dehydrogenase is less active and results in an accumulation of acetaldehyde and slower conversion to acetic acid. It is coded by the ALDH $2 * 2$ allele, whose low frequency is a protective factor against alcoholism ${ }^{(4)}$.

Special attention should be given to alcoholic women to help them recover, to care for the children, and to avoid further children from being affected ${ }^{(4,14)}$.

Lemoine et al., in France, in $1968^{(15)}$ and Jones and Smith $^{(16)}$, in the USA, in 1973, described the anomalies found in children of alcohol-consuming pregnant women; these have been confirmed by others ${ }^{(17)}$.

In 1996, the U.S. Institute of Medicine of the National Academy of Sciences (IOM), in Washington, introduced the terms ARBD and ARND to describe changes in the children of alcoholic pregnant women, which were not found in FAS ${ }^{(18,19)}$.

Astley and Clarren, in 2000, published the diagnostic criteria for FAS and fetal alcohol effect (FAE), which are known as the Washington criteria ${ }^{(20)}$ or the 4-Digit Diagnostic Code ${ }^{(21)}$. They objectively defined the facial phenotype of FAS and wrote an illustrated guide of the upper lip and the nasal philtrum (University of Washington Lip-Philtrum Guide) $)^{(1,20)}$.

In 2004, the Centers for Disease Control and Prevention (CDC) brought together scientists to publish the diagnostic guide for FAS, its prevention and follow-up, and write recommendations for identifying pregnant women at risk for alcohol consumption and intervening ${ }^{(2,3)}$.

In 2004, in the USA, the National Organization on Fetal Alcohol Syndrome (NOFAS) defined the 
term FASD to encompass all the consequences for people whose mothers consumed alcohol during their gestation $^{(1-3,21)}$.

Reports worldwide on FAS have varied ${ }^{(2)}$. Estimates suggested a mean of 0.5-2 cases/1,000 live births ${ }^{(11)}$. Based on this prevalence, the CDC expects there will be 1,000 to 6,000 children with FAS among 4 million children born live every year ${ }^{(2,3)}$.

The prevalence of FAS in the USA is $0.5-2$ cases $/ 1,000$ births. It has been estimated that for each child with FAS there are three children that do not present all the features of this syndrome, but that have neurobehavioral deficits affecting learning and behavior due to prenatal alcohol exposure ${ }^{(22)}$.

A study conducted at a public maternity hospital in São Paulo, Brazil, in 2008, showed that FAS was diagnosed in 1.52/1,000 live births. This same study also suggested that a diagnosis of ARBD was possible in 3.05/1,000 live births, and that 34.11/1,000 live births were at a risk of having $\mathrm{ARND}^{(9)}$.

\section{Effects of ethyl alcohol}

Alcohol is more bioavailable in women compared to men because of increased alcohol absorption, a smaller body amount of water, and a higher proportion of body fat, which results in higher blood levels of alcohol ${ }^{(23)}$. Women are less tolerant of alcohol than men, and are more vulnerable to clinical complications and mortality risks ${ }^{(24)}$.

Excessive alcohol drinking within a short time span is known as "binge drinking", which may result in damage to health. Heavy alcohol consumption or binge drinking is defined as drinking five or more units (men), or four or more units (women) ${ }^{(5)}$.

The CDC and the National Task Force on Fetal Alcohol Syndrome/Fetal Alcohol Effect (NTFFAS/ FAE) recommend that fertile non-pregnant women drink no more than seven drinks per week, drinking on not more than three occasions per week ${ }^{(2,3)}$. This pattern in women is only safe if they are not pregnant; in this case, full cessation of drinking is recommended ${ }^{(23)}$.

Ethanol crosses the placenta unchanged in both directions due to a concentration gradient, which results in the fetus having similar levels to those of the mother ${ }^{(14,16)}$. However, immaturity and poor enzyme function means that alcohol is metabolized and eliminated at a slower rate, resulting in increased fetal exposure. Amniotic fluid is considered a reservoir of ethanol and acetaldehyde, which further exposes the fetus ${ }^{(16)}$.

When a pregnant woman drinks alcoholic beverages, so does the fetus ${ }^{(22)}$. During gestation, any dose of alcohol that is consumed may result in developmental changes ${ }^{(25)}$. The probability of newborn involvement and the severity of the syndrome depend on the dose of alcohol consumed by the mother, her consumption pattern, maternal and fetal blood alcohol levels and metabolism, maternal health, gestational age during which the fetus is exposed, and genetic susceptibility of the fetus ${ }^{(16,19,25-28)}$.

Alcohol affects the fetus directly or indirectly, affecting its growth. It interferes with placental transportation of essential nutrients for fetal development; alcohol also may result in maternal malnutrition ${ }^{(29)}$. Vasoconstriction of the placenta and umbilical vessels may result in hypoxemia ${ }^{(25)}$.

There are no markers to show the specific effects of alcohol on the fetus or the effect of dose on the mechanisms underlying the syndrome ${ }^{(30)}$. Probably more than one mechanism will explain the harmful effects of alcohol on the fetus ${ }^{(31)}$.

Alcohol easily crosses the blood-brain barrier, which may result in complex effects on brain development ${ }^{(14,29)}$. It may cause the death of certain brain cells, or may alter their function ${ }^{(29)}$.

Alcohol may affect the fetal central nervous system (CNS) at any gestational age, especially within the first five weeks ${ }^{(15,18,28)}$. Microcephaly and/or microencephaly may ensue because of diminished brain growth ${ }^{(14)}$. Functional changes of the corpus callosus, cerebellum, and basal ganglia are seen consistently ${ }^{(3)}$. Agenesis of the corpus callosus is one of the most frequent anomalies ${ }^{(32)}$. Structural changes of the CNS that suggest FAS may occur without detectable functional loss ${ }^{(2,3)}$.

\section{Clinical features and diagnostic criteria of fetal alcohol spectrum disorders}

Not all children of mothers that consume alcoholic beverages during pregnancy develop such effects; nevertheless, a safe level of alcohol consumption during pregnancy is not known $^{(16,31)}$.

FAS has a typical pattern of facial alterations (Figure 1), pre- and/or postnatal growth restriction, and evidence of structural and/or functional CNS changes due to intrauterine alcohol exposure ${ }^{(15,26,29-31)}$. These findings were adapted from the IOM diagnostic criteria $(1996)^{(15,18,19)}$. Hoyme et al. clarified the features of ARBD (Chart 2) and ARND (Chart 3) and made them more specific and applicable in the clinical setting ${ }^{(1)}$.

Facial dysmorphism is included in FASD, but is often absent; it is less important compared to the impact of prenatal alcohol exposure on brain function. However, the facial phenotype - with an altered midline - is the most sensitive and specific marker for alcohol-related brain damage ${ }^{(21)}$.

Abrupt removal of the newborn from an alcoholaltered intrauterine environment may result in the alcohol 


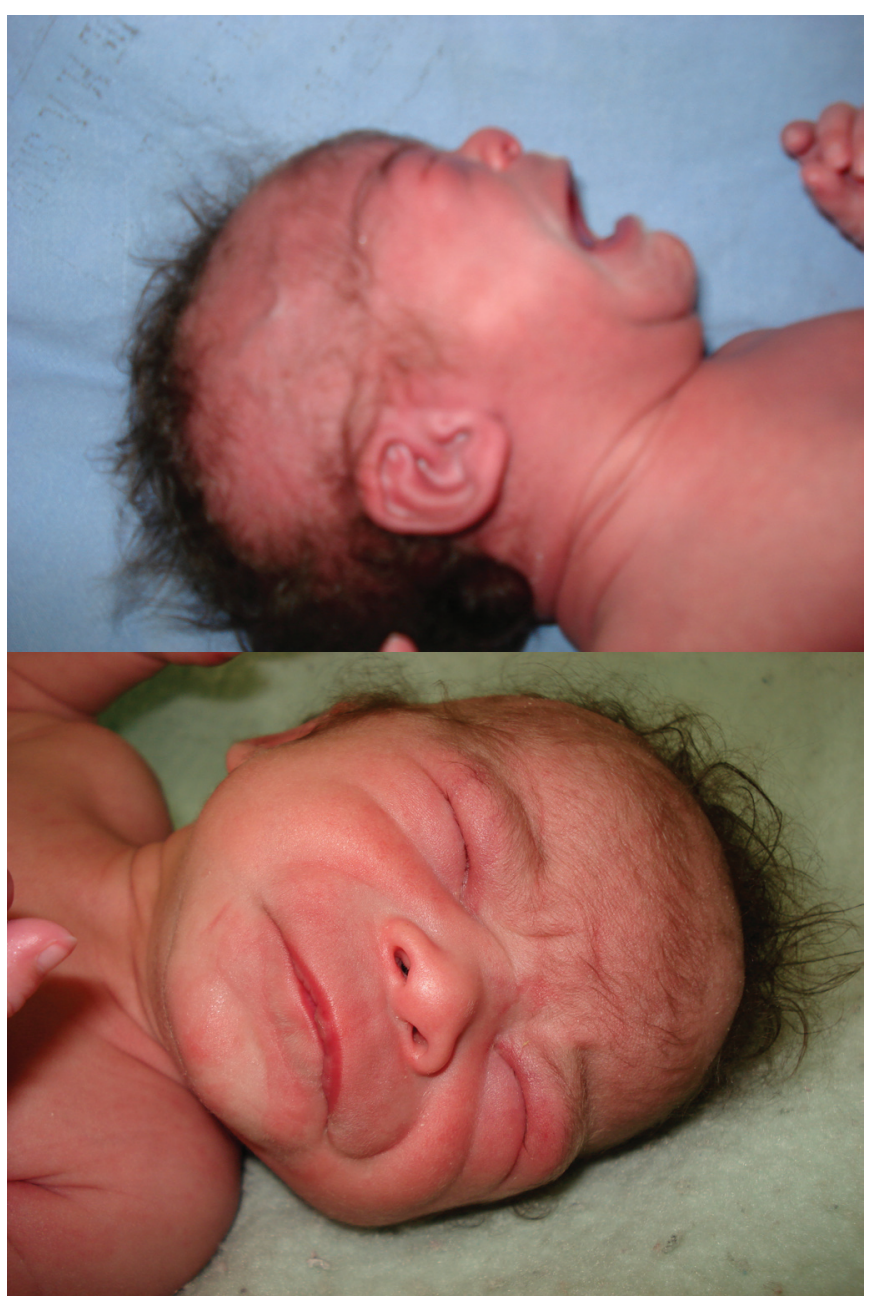

Figure 1. Newborn with birth weight, head circumference, length, palpebral fissure and red upper lip border smaller than the $10^{\text {th }}$ percentile for gestational age, anteverted nose, smooth philtrum, low set pinna and abstinence syndrome

abstinence syndrome, which manifests as irritability, hiperexcitability, hipersensitivity, hypotonia, tremors, muscle tension with opisthotonos, altered sleep patterns, frequent states of alert, sweating, apnea, tachypnea, refusal of food, and bonding difficulties ${ }^{(14,18)}$. Alcohol metabolism in neonates is slow; thus, the abstinence syndrome may be delayed, usually arising during the second day of life ${ }^{(14)}$.

The mean intake of milk by nursing children is $20 \%$ less, three to four hours after mothers have consumed alcohol ${ }^{(33)}$; this is because oxytocin production in mothers is decreased, which, in turn, reduces the ejection of milk ${ }^{(34)}$.

About $2 \%$ of the alcohol consumed by nursing mothers is transferred to milk, where it appears 30 to 60 minutes later. Eye movements during sleep are consequently decreased and gross movements are also altered ${ }^{(33)}$.

Although the effects of alcohol on newborns are known, the children are often not diagnosed because diagnostic criteria are not uniform ${ }^{(2,3)}$. Two studies defined the diagnostic criteria for children exposed to alcohol during intrauterine life: the IOM criteria (1996), and the Washington criteria
$(2000)^{(1)}$. CDC scientists meeting from 2002 to 2004 established the diagnostic criteria of the $\mathrm{FAS}^{(3)}$.

In 1996, the IOM defined five FAS/FAE categories (Chart 4). These are vague and confusing, because they do not define the facial phenotype, the degree of growth restriction, or neurobehavioral and cognitive changes resulting from these conditions ${ }^{(1)}$.

The Washington criteria (Chart 5) reflect the degree of expression of four key features in the FAS: growth restriction, facial phenotype in the FAS, CNS alterations or dysfunction, and intrauterine exposure to alcohol. The expression of each feature is classified independently on a one-to-four scale, where 1 is normal and 4 is maximum expression $^{(20)}$.

The Washington criteria objectively defined the facial phenotype of the FAS and provided an illustrated guide of the upper lip and the nasal philtrum to facilitate evaluations (University of Washington Lip-Philtrum Guide). It describes five categories for the upper lip and nasal philtrum, which are assessed separately by comparing faces of children ranging from normal to classical FAS features. A score 1 is completely normal and a score 5 is indicative of FAS $^{(1,20,21)}$. The Washington criteria show that for a diagnosis, the palpebral fissure has to be smaller or equal to two standard deviations, and the nasal philtrum and upper lip should be categories 4 or 5 in the illustrated guide ${ }^{(21)}$.

According to the CDC (2002-2004), a diagnosis of the FAS requires at least three findings: the three facial dysmorphisms described above, pre- and postnatal growth restriction (weight and/or height), and structural, neurological or functional CNS abnormalities (Chart 6). Unconfirmed exposure to alcohol during pregnancy should not exclude the diagnosis of the FAS if all other criteria are present. Certainty that the mother did not consume alcohol during pregnancy makes the diagnosis of the FAS inappropriate. Prenatal exposure to alcohol alone is not enough for a diagnosis of the $\mathrm{FAS}^{(2)}$.

Growth and facial anthropometrics are specific for each population and race. Some facial features of the FAS, such as in the upper lip and philtrum, may become less easily recognizable with age, making the diagnosis less accurate in older patients ${ }^{(21)}$.

\section{Diagnosis, follow-up and treatment}

Early diagnosis and intervention in children reduce the risk of future incapacitation ${ }^{(2,35)}$. For families, it provides information about the patients health issues, thereby setting appropriate expectations for the child, increasing the access to social service, education, and possible government support. For Public Health, the diagnosis provides the basis for recording the incidence and prevalence of this condition, which support studies for healthcare planning, and social and educational interventions ${ }^{(21,36)}$. 
It is necessary to standardize the diagnostic routines $^{(21)}$. Except for FAS, there is not enough scientific evidence to define diagnostic criteria for other prenatal alcohol-related conditions ${ }^{(2)}$. A qualified well-trained and experienced multidisciplinary team is essential for diagnosis and treatment recommendations, because of the complexity and variation in the expression of alterations $^{(21)}$.

The diagnosis of FAS is easier from ages 2 to 11 years, when facial dysmorphism is more evident and typical CNS dysfunction manifest clinically ${ }^{(4,14,15,18)}$.

The diagnosis of FASD is difficult in newborns; many cases are lost because the pattern of alcohol intake in pregnant women is unknown, or there is little medical experience with this disease, or because neurodevelopment and cognitive/behavioral function cannot be easily assessed at this age ${ }^{(17,35,37)}$.

The neonatal diagnosis depends on facial features, intrauterine growth restriction relative to weight, head circumference and length associated with intrauterine alcohol exposure. Intrauterine exposure to alcohol should be investigated if there is growth restriction and congenital malformation $^{(14,18)}$.

Certain syndromes manifest similarly to FAS, and should be included in the differential diagnosis. Except for toluene embryopathy, no other known syndromes present small palpebral fissures, thin red lip borders, and a smooth philtrum, concomitantlyy ${ }^{(2-3)}$.

Children and their families should be referred to specialized medical units if the mother consumed seven or more drinks per week and/or three or more drinks each time on several occasions. Absence of diagnostic criteria requires follow-up at primary healthcare centers of children during growth and development ${ }^{(2,3)}$.

If prenatal alcohol exposure is unknown, children or individuals are referred for care if there are concerns or reports about the possibility of the FAS, and if the three typical facial features of the syndrome, or one or more typical facial features with lower weight and/or height, or one or more typical facial features with one or more CNS alterations, and one or more typical facial features with compromised growth and one or more CNS alterations are present ${ }^{(2,3)}$.

The possibility of prenatal alcohol exposure should be considered if there is maternal premature death due to trauma or alcohol-related diseases, if the mother was living with an alcoholic family member, if there is a current report or a history of abuse or negligence, if there is current or past involvement with child-protection agencies, and if children are cared by other family members ${ }^{(2)}$.

Individuals with learning and behavioral disabilities, no physical or dysmorphic alterations, and unknown prenatal alcohol exposure also require an evaluation to identify and treat these problems ${ }^{(21)}$.
There is no specific therapy for FAS/FAE; thus, children and their families end up having to live with the consequences of damage due to intrauterine alcohol exposure $^{(38)}$. Health problems in children should be treated and/or monitored by specialists and there should be preventive measures for patients and their families ${ }^{(3,30)}$.

Although efforts have been made to reinforce and diversify interventions for the FAS, a recent review ${ }^{(39)}$ concluded that there is still little evidence in the literature about the quality of specific measures for dealing with the FAS; however, currently, seven randomized studies are being carried out to face this issue.

\section{Prevention}

FASD comprise permanent and irreversible anomalies; thus, prevention is the best approach ${ }^{(3,30,38)}$. Its anomalies are fully avoided if women consume no alcohol during pregnancy, from immediately before conception until childbirth ${ }^{(35,38)}$.

The CDC, the NTFFAS/FAE, and the U.S. Surgeon General's Advisory Council recommend pregnant women or those that wish to become pregnant or have risk to become pregnant to avoid consuming alcoholic beverages $^{(2-4,22,27,28,35)}$. The American Academy of Pediatrics and the American College of Obstetricians and Gynecologists have issued the same recommendation ${ }^{(38)}$.

Preventing prenatal alcohol exposure requires identifying the women that consume alcohol. Pregnant and nursing women, those that wish to become pregnant, and sexually active women that are not on contraceptives should be inquired about their alcohol consuming habits ${ }^{(3)}$.

Several opportunities for detecting alcohol consumption arise during prenatal visits, when women are seen regularly by a healthcare team ${ }^{(40)}$.

Low laboratory biomarker sensitivity, the possibility that changes may only occur in the presence of large amounts of alcohol, and the elevated cost of these exams have made this approach unfeasible for screening such women ${ }^{(3)}$.

The key for preventing FASD is to promote awarenessraising programs for pregnant women about the dangers of prenatal alcohol exposure ${ }^{(3)}$.

\section{CONCLUSION}

The causes and consequences of FASD at an individual and collective level are well-known and fully avoidable.

Healthcare professionals have the duty to avoid the harm that alcohol causes to the fetus - by identifying women that consume alcoholic beverages - and to recognize affected children in the neonatal period.

Government initiatives and the population should work together to plan and execute measures for preventing and minimizing all the consequences, for the fetus, of alcohol consumption by their mothers. 


\section{ACKNOWLEDGEMENTS}

We wish to acknowledge Professor Conceição Aparecida de Mattos Segre, $\mathrm{PhD}$, for her suggestions in writing this article.

\section{REFERENCES}

1. Hoyme HE, May PA, Kalberg WO, Kodituwakku P, Gossage JP, Trujillo PM, et al. A practical clinical approach to diagnosis of fetal alcohol spectrum disorders: clarification of the 1996 institute of medicine criteria. Pediatrics. 2005;115(1): 3947.

2. Bertrand J, Floyd LL, Weber MK; Fetal Alcohol Syndrome Prevention Team,Division of Birth Defects and Developmental Disabilities, National Center on Birth Defects and Developmental Disabilities, Centers for Disease Control and Prevention (CDC). Guidelines for identifying and referring persons with fetal alcohol syndrome. MMWR Recomm Rep. 2005;54(RR-11):1-14.

3. Fetal alcohol syndrome: guidelines for referral and diagnosis. National Center on Birth Defects and Developmental Disabilities, Centers for Control and Prevention, Department of Health and Human Services in coordination with National Task Force on Fetal Alcohol Syndrome and Fetal Alcohol Effect [Internet]. 2004 [cited 2009 Mar 9]. Available from: http://www.cdc.gov/ncbddd/fasd/documents/FAS guidelines_accessble.pdf

4. Riley EP, Guerri C, Calhoun F, Charness ME, Foroud TM, Li TK, et al. Prenatal alcohol exposure: advancing knowledge through international collaborations. Alcohol Clin Exp Res. 2003;27(1):118-35.

5. Felix JA. Apresentação. In: SENAD, ed. I Levantamento nacional sobre os padrões de consumo de álcool na população brasileira. Brasília: Secretaria Nacional Antidrogas; 2007. p. 5. [Internet] [citado 2008 Abr 2]. Available from: http://www.obid.senad.gov.br/portais/OBID/biblioteca/documentos/ Dados_Estatisticos/população_brasileira/Padroes_consumo_alcool_populacao brasileira/327716.pdf

6. World Health Organization. Management of substance abuse. Alcohol [Internet]. 2008 [cited 2008 Mar 9]. Available from: http://www.who.int/substance_abuse/ facts/alcohol/en/index.html

7. World Health Organization. The World Health Report 2001. Mental health: new understanding, new hope. Relatório Mundial da Saúde, 2001. Lisboa: Climepsi; 2002.

8. Moraes $\mathrm{CL}$, Reichenheim ME. Rastreamento de uso de álcool por gestantes de serviços públicos de saúde do Rio de Janeiro. Rev Saúde Pública. 2007;41 (5):695703.

9. Mesquita MA, Segre CAM. Frequência dos efeitos do álcool no feto e padrão de consumo de bebidas alcoólicas pelas gestantes de maternidade pública da cidade de São Paulo. Rev Bras Crescimento Desenvolv Hum. 2009;19(1):6377.

10. May PA, Gossage JP, Brooke LE, Snell CL, Marais AS, Hendricks LS, et al. Maternal risk factors for fetal alcohol syndrome in the Western cape province of South Africa: a population-based study. Am J Public Health. 2005;95(7):1190-9.

11. May PA, Gossage JP. Estimating the prevalence of fetal alcohol syndrome. A summary. Alcohol Res Health. 2001;25(3):159-67.

12. Ethen MK, Ramadhani TA, Scheuerle AE, Canfield MA, Wyszynski DF, Druschel CM, Romitti PA; National Birth Defects Prevention Study. Alcohol consumption by women before and during pregnancy. Matern Child Health J. 2009;13(2):274-85.

13. Warren KR, Calhoun FJ, May PA, Viljoen DL, Li TK, Tanaka H, et al. Fetal alcohol syndrome: an international perspective. Alcohol Clin Exp Res. 2001;25/5 Suppl (SBRA):202S-206S.

14. Jones MW, Bass WT. Fetal alcohol syndrome. Neonatal Netw. 2003;22(3):63-70.

15. LemoineP, HarouseauH, Borteryu JT,MenuetJC. Lesenfants des parentsalcooliques. Anomalies observées à propos de 127 cas. Ouest Médical.1968;21:476-82.

16. Jones $\mathrm{KL}$, Smith DW. Recognition of the fetal alcohol syndrome in early infancy. Lancet. 1973;302(7836):999-1001.
17. Lemoine P, Harousseau H, Borteyru JP, Menuet JC. Children of alcoholic parents--observed anomalies: discussion of 127 cases. Ther Drug Monit. 2003;25(2):132-6.

18. Thackray H, Tifft C. Fetal alcohol syndrome. Pediatr Rev. 2001;22(2):47-55.

19. Hannigan JH, Armant DR. Alcohol in pregnancy and neonatal outcome. Semin Neonatol. 2000;5(3):243-54.

20. Astley SJ, Clarren SK. Diagnosing the full spectrum of fetal alcohol-exposed individuals: introducing the 4-digit diagnostic code. Alcohol Alcohol. 2000;35(4):40010.

21. Chudley AE, Conry J, Cook JL, Loock C, Rosales T, LeBlanc N; Public Health Agency of Canada's National Advisory Committee on Fetal Alcohol Spectrum Disorder. Fetal alcohol spectrum disorder: Canadian guidelines for diagnosis. CMAJ. 2005;172(5 Suppl):S1-S21.

22. U.S. Surgeon General Advisory on Alcohol Use in Pregnancy. Urges women who are pregnant or who may become pregnant to abstain from alcohol [Internet]. Washington (DC): US Department of Health and Human Services; 2005 [cited 2009 Apr 2]. Available from: http://www.surgeongeneral.gov/pressreleases/ sg02222005.html

23. Grinfeld H. Consumo nocivo de álcool durante a gravidez. In: Andrade AG, Anthony JC, editors. Álcool e suas consequências: uma abordagem multiconceitual. São Paulo: Manole; 2009. p.179-99.

24. Nóbrega MPSS, Oliveira EM. Mulheres usuárias de álcool: análise qualitativa. Rev Saúde Pública. 2005;39(5):816-23.

25. Grinfeld H, Segre CAM, Chadi G, Goldenberg S. 0 alcoolismo na gravidez e os efeitos na prole. Rev Paul Pediatr. 2000;18(1):41-9.

26. Mattson SN, Schoenfeld AM, Riley EP. Teratogenic effects of alcohol on brain and behavior. Alcohol Res Health. 2001;25(3):185-91.

27. American Academy of Pediatrics. Committee on Substance Abuse and Committee on Children With Disabilities. Fetal alcohol syndrome and alcohol-related neurodevelopmental disorders. Pediatrics. 2000;106(2 Pt 1):358-61.

28. Maier SE, West JR. Drinking patterns and alcohol-related birth defects. Alcohol Res Health. 2001;25(3):168-74.

29. Goodlett CR, Horn KH. Mechanisms of alcohol-induced damage to the developing nervous system. Alcohol Res Health. 2001;25(3):175-84.

30. Núcleo Einstein de Álcool e Drogas (NEAD). Síndrome alcoólica fetal [Internet]. 2003 [citado 2010 Fev 4]. Disponível em: http://apps.einstein.br/alcooledrogas/ novosite/complicacoes_gravidez_sindrome.htm

31. National Organization on Fetal Alcohol Syndrome. What is fetal alcohol syndrome? [Internet]. 2003 [cited 2003 Jun 15]. Available from: http://www.nofas.org/main/ what is_FAS.htm

32. Roebuck-Spencer TM, Mattson SN, Marion SD, Brown WS, Riley EP. Bimanual coordination in alcohol-exposed children: role of the corpus callosum. J Int Neuropsychol Soc. 2004;10(4):536-48.

33. Mennella JA. Alcohol's effect on lactation. Alcohol Res Health. 2001;25(3):230-4.

34. Mennella JA, Pepino MY, Teff KL. Acute alcohol consumption disrupts the hormonal milieu of lactating women. J Clin Endocrinol Metab. 2005;90(4):1979-85.

35. Floyd RL, O'Connor MJ, Sokol RJ, Bertrand J, Cordero JF. Recognition and prevention of fetal alcohol syndrome. Obstet Gynecol. 2005;106(5 Pt 1):1059-64.

36. Peadon E, O'Leary C, Bower C, Elliott E. Impacts of alcohol use in pregnancy - the role of the GP. Aust Family Physician. 2007;36(11):935-9.

37. Gahagan S, Sharpe T, Brimacombe M, Fry-Johnson Y, Levine R, Mengel M, et al. Pediatricians' knowledge, training, and experience in the care of children with fetal alcohol syndrome. Pediatrics. 2006;118(3):e657-68.

38. Cook JD. Biochemical markers of alcohol use in pregnant woman. Clin Biochem. 2003;36(1):9-19.

39. Peadon E, Rhys-Jones B, Bower C, Elliott EJ. Systematic review of interventions for children with Fetal Alcohol Spectrum Disorders. BMC Pediatr. 2009;9:35.

40. Pinheiro SN, Laprega MR, Furtado EF. Morbidade psiquiátrica e uso de álcool em gestantes usuárias do Sistema Único de Saúde. Rev Saúde Pública. 2005;39(4):593-8. 